\title{
BSA Involvement Score 1
}

National Cancer Institute

\section{Source}

National Cancer Institute. BSA Involvement Score 1. NCI Thesaurus. Code C131036.

$1-18 \%$ of body surface area involved. 